\title{
Pemakaian Modul Pembelajaran Sejarah di SMA N 6 Padang
}

\author{
Oleh : Nanda Permana \\ Pendidikan Sejarah PPS UNJ
}

\begin{abstract}
Background of this research is the module who was made by the teachers of history at 6th high school. Module was purposed to make the student to be easier in their study. Module gives them something that teacher can't do and it has something different than other sources. Learning by the module is a teacher history initiative, this can be seen from this school is the only one who uses this module. This research aims to know about the opinion of teachers and students about the effectiveness of the module in the learning process. Kind of this research was descriptive-qualitative. The data taken from two history teachers, sixteen students of class X1, 6 student of class X2 and sconehool leader. The data obtained using the techniques of observation, interviews and documentation. Validity of the data in this study were tested using data triangulation technique. Then the data were analyzed with data reduction, data presentation, and conclusion. The results showed that, the modules made by the subject teachers of history used by all students, so that modules made effective then teachers should refer to the theory proposed by M. Rogers Everret where modules have advantages, consistent, complexity, can be tested and observed. The fifth aspect presented by Rogers is already almost owned by modules made by the subject teachers of history.

Keyword: result of learning history, cooperative learning, team assisted individualization
\end{abstract}

\begin{abstract}
Abstrak
Penelitian ini dilatarbelakangi oleh modul yang dibuat oleh guru mata pelajaran sejarah yang digunakan dalam lingkungan SMA Negeri 6 Padang, karena modul memberikan kelebihan dari bahan ajar lain seperti materi yang lebih lengkap dan lembar kerja yang lebih banyak di banding dengan LKS. SMA Negeri 6 adalah sekolah yang satu-satunya memiliki modul sebagai bahan ajar pada mata pelajaran sejarah. Penelitian ini bertujuan untuk mengetahui pendapat guru dan siswa tentang pemakaian modul dalam pembelajaran sejarah di SMA Negeri 6 Padang. Jenis penelitian ini adalah deskriptif kualitatif dengan. Data diambil dari informan 2 orang guru sejarah, 22 orang siswa yang masing-masing terdiri dari 16 orang siswa kelas X1 dan 6 orang siswa kelas X2 dan Pemimpin sekolah melalui teknik observasi, wawancara, dan dokumentasi. Keabsahan data dalam penelitian ini diuji dengan menggunakan teknik triagulasi data, kemudian data yang terkumpul dianalisis reduksi data, penyajian data, dan penarikan kesimpulan, agar modul yang dibuat efektif maka guru harus mengacu pada teori yang dikemukakan oleh Everret M. Rogers dimana modul memiliki keunggulan, konsisten, kerumitan, dapat diuji dan dapat diamati. Dari hasil penelitian dapat disimpulkan bahwa modul yang dibuat oleh guru mata pelajaran sejarah sudah hampir mendekati.
\end{abstract}

Kata Kunci: hasil belajar sejarah, metode Pembelajaran Kooperatif, team Assisted Individualization

\section{PENDAHULUAN}

Pendidikan merupakan faktor utama yang sangat membangun di Indonesia karena majunya suatu Negara ditentukan oleh mutu pendidikan. Pendidikan sebagaimana yang dinyatakan di dalam Undang-Undang Nomor 20 Tahun 2003 tentang Sistem Pendidikan Nasional pada Pasal 1 angka 1 adalah: usaha sadar dan terencana untuk mewujudkan suasana belajar dan proses pembelajaran agar 
peserta didik secara aktif mengembangkan potensi dirinya untuk memiliki kekuatan spiritual keagamaan, pengendalian diri, kepribadian, kecerdasan, akhlak mulia, serta ketvferampilan yang diperlukan dirinya, masyarakat, bangsa dan negara (Depdikbud, 2013: 83).

Dalam PP nomor 19 tahun 2005 Pasal 20, diisyaratkan bahwa guru diharapkan mengembangkan materi pembelajaran, yang kemudian dipertegas melalui Peraturan Menteri Pendidikan Nasional (Permendiknas) nomor 41 tahun 2007 tentang Standar Proses, yang antara lain mengatur tentang perencanaan proses pembelajaran yang mensyaratkan bagi pendidik pada satuan pendidikan untuk mengembangkan rencana pelaksanaan pembelajaran (RPP). Salah satu elemen dalam RPP adalah sumber belajar. Dengan demikian, guru diharapkan untuk mengembangkan bahan ajar sebagai salah satu sumber belajar (Depdiknas, 2008: 1).

Dari uraian diatas dapat diketahui bahwa guru harus mampu membuat bahan ajar yang mempermudah siswa memahami materi pembelajaran, salah satu bahan ajar yang harus dibuat guru adalah modul, dengan modul diharapkan siswa mampu belajar sendiri di rumah dan guru hanya sebagai fasilitator. Sistem pengajaran dengan modul adalah suatu sistem penyampaian yang telah dipilih dalam rangka pengembangan sistem pendidikan yang lebih efisien, relevan, dan efektif. Pada sekolah-sekolah biasa ternyata amat banyak waktu yang digunakan oleh murid-murid untuk mendengarkan dan mencatat. Sedangkan proses belajar itu sendiri berjalan dengan kekurangan waktu. Bahkan banyak kegiatan belajar yang sebenarnya terjadi diluar pengawasan guru. Keadaan demikian tidak memungkinkan guru mengawasi dan membantu murid dalam mencari kebiasaan yang baik dalam belajar, sedang sementara itu waktu sekolah kurang dimanfaatkan untuk keaktifan belajar tetapi hanya untuk mendengarkan dan mencatat keteranganketerangan pelajaran yang diberikan oleh guru (Suryosubroto, 1983: 11).

Jadi untuk mempermudah siswa dalam proses pembelajaran di sekolah maupun di rumah, guru sejarah di SMA Negeri 6 Padang membuat modul yang digunakan dalam proses pembelajaran dan digunakan dalam lingkungan SMA 6 Padang, karena modul memberikan kelebihan dari bahan ajar lain seperti materi yang lebih lengkap dan lembar kerja yang lebih banyak di banding dengan LKS. Pembelajaran dengan sistem modul adalah bentuk insiatif guru sejarah, karena SMA Negeri 6 adalah sekolah yang satu-satunya memiliki modul sebagai bahan ajar pada mata pelajaran sejarah, modul itu dibuat sendiri oleh guru mata pelajaran sejarah. Hal ini merupakan inovasi dalam proses pembelajaran sejarah, karena hanya mata pelajaran sejarah yang memiliki modul (observasi tanggal 24 Desember 2014)

Dari studi pendahuluan yang telah peneliti lakukan pada tanggal 24 Desember 2014 dengan salah seorang guru sejarah yaitu SP bahwa "SMA Negeri 6 menggunakan bahan ajar modul yang dibuat oleh guru mata pelajaran dan digunakan disetiap materi pelajaran serta digunakan dalam lingkungan SMA Negeri 6 kota Padang". Hal ini merupakan inovasi dalam pembelajaran sejarah, karena guru membuat sendiri bahan belajar dan digunakan dalam lingkungan SMA Negeri 6 Padang.

Berdasarkan uraian pada latarbelakang timbul pertanyaan bagi peneliti terhadap pemakaian modul yang digunakan, apakah berjalan lancar 
atau memiliki hambatan-hambatan dalam rangka proses pembelajaran. Serta bagaiman kesan siswa dalam rangka perbaikan pembelajaran. Dengan demikian peneliti ingin mengkaji permasalahan ini dalam suatu bentuk penelitian dengan judul : "Pemakaian Modul Pembelajaran Sejarah Di SMA Negeri 6 Padang"

Proses Pembelajaran. Dalam sistem pendidikan di sekolah maupun di perguruan tinggi kegiatan belajar merupakan yang pokok. Menurut Hilgard dan Brower (Hamalik, 2004:45) belajar adalah perubahan dalam perbuatan melalui aktivitas, praktek dan pengalaman. Selain itu belajar menurut Winkel (1996:53) adalah suatu aktivitas mental/psikis yang berlangsung dalam interaksi aktif dengan lingkungan yang menghasilkan perubahan-perubahan dalam pengetahuan, pemahaman, keterampilan dan sikap. Sedangkan proses menurut Sudjana (2001:22) adalah kegiatan yang dilakukan oleh peserta didik dalam mencapai tujuan pengajaran. Sementara Menurut Ahmadi (1993:20) proses belajar adalah suatu bentuk pertumbuhan atau perubahan dalam diri seseorang yang dinyatakan dalam cara-cara bertingkah laku yang baru berkat pengalaman dan latihan.

Sedangkan pembelajaran merupakan terjemahan dari kata instruction yang dalam bahasa Yunani disebut instructus atau intruere yang berarti menyampaikan pikiran, dengan demikian arti instruksional adalah menyampaikan pikiran atua ide yang telah diolah secara bermakna melalui pembelajaran (Warsita, 2008: 265). Kegiatan pembelajaran dirancang untuk memberikan pengalaman belajar yang melibatkan proses mental dan fisik melalui interaksi antara peserta didik, peserta didik dengan guru, lingkungan dan sumber belajar lainnya dalam rangka pencapaian kompetensi dasar. Pembelajaran sejarah bukan hanya sebagai proses transfer ide, akan tetapi juga proses pendewasaan peserta didik untuk memahami identitas, jati diri dan kepribadian bangsa melalui pemahaman terhadap peristiwa sejarah (Susanto, 2004: 56).

Modul adalah salah suatu satuan pelajaran yang berisi rangkaian penyampaian rangkaian materi dengan pendekatan sedemikian rupa sehingga dapat dipelajari sendiri oleh siswa tanpa bantuan dari guru (Arikunto, 2010: 13). Sedangkan menurut Suryosubroto (1983) Modul adalah suatu unit program belajar mengajar terkecil yang secara terperinci menggariskan"

1) Tujuan Intruksi yang akan dicapai

2) Topik yang akan dijadikan pangkal proses belajar-mengajar

3) Pokok-pokok materi yang akan dipelajari

4) Kedudukan dan fungsi modul dalam kesatuan program yang lebih luas

5) Peranan guru dalam proses belajar mengajar

Berdasarkan pendapat diatas dapat disimpulkan bahwa modul adalah seperangkat bahan ajar yang disajikan secara sistematis sehingga penggunanya dapat belajar dengan atau tanpa seorang fasilitator/guru. Dengan demikian maka sebuah modul harus dapat dijadikan sebuah bahan ajar sebagai pengganti fungsi guru. Kalau guru memiliki fungsi menjelaskan sesuatu maka modul harus mampu menjelaskan sesuatu dengan bahasa yang mudah diterima peserta didik sesuai dengan tingkat pengetahuan dan usianya. 
Sifat Modul. Menurut (Suryosubroto, 1983:17) Sifat-sifat khas modul dapat dikemukakan sebagai berikut: (1) Modul merupakan unit pelajar terkecil dan lengkap, (2) Modul memuat rangkaian kegiatan belajar yang direncanakan dan sistematik, (3) Modul memuat tujuan belajar yang dirumuskan secara jelas dan spesifik, (4) Modul memungkinkan siswa belajar sendiri

Maksud dan tujuan digunakan modul didalam proses belajar mengajar ialah (Suryosubroto, 1983:17)

1) Tujuan pendidikan dapat dicapai secara efisien

2) Murid dapat menguikuti program pendidikan sesuai dengan kecepatan dan kemampuannya sendiri

3) Murid dapat menilai dan mengetahui hasil belajarnya sendiri secara berkelanjutan

4) Murid benar-benar menjadi titik pusat kegiatan belajar-mengajar

Penulisan Modul. Menurut Depdiknas dalam panduan pengembangan bahan ajar (2008:21) Penulisan moduldapat dilakukan dengan langkah-langkah sebagai berikut: (1) Perumusan KD yang harus dikuasai,

(2) Menentukan alat evaluasi/penilaian,

(3) Evaluasi, (4)Penyusunan Materi, (5) Urutan pembelajaran, (6) Struktur bahan ajar/modul

Teori yang dipakai dalam penelitian ini adalah teori inovasi yang dikemukakan oleh Everett M. Rogers. Ia menegemukakan bahwah inovasi adalah "an idea, practice, or object perceived as new by the individual." (suatu gagasan, praktek, atau benda yang dianggap/dirasa baru oleh individu), artinya inovasi adalah setiap ide yang dibayangkan sebagai sesuatu yang baru oleh seorang individu.
Ide itu mungkin sudah ada ditempat lain atau dikalangan orang lain, tetapi tidak dapat mengubah pengaruhnya terhadapa individu yang menemukanya dan yang membayangkannya sebagai sesuatu yang baru ( Lauer, 1993: 227)

Selanjutnya faktor-faktor yang dijadikan pertimbangan pihak adopter (pengguna inovasi) dalam membuat keputusan untuk menerima atau menolak produk suatu inovasi jika diakaitan dengan pemikiran Everett $M$. Rogers (1983: 15) dalam diffusion of Innovasion di pegaruhi oleh lima aspek inovasi, yaitu: (1) keunggulan relative, (2) konsisten, (3) kerumitan, (4) dapat diuji, (5) dapat diamati.

Penelitian ini adalah deskriptif dengan pendekatan kualitatif. Dalam penelitian ini adalah 2 orang guru sejarah yang aktif mengajar dan merupakan informan kunci, kepala sekolah, serta siswa kelas $\mathrm{X}$ yang berjumlah 22 orang, yang masing-masing terdiri dari 16 orang siswa kelas X1 dan 6 orang siswa kelas X2. Teknik pengumpulan data yang digunakan dalam penelitian ini adalah Observasi, Wawancara tidak berstruktur dan Studi dokumentasi. Teknik analisi data yaitu Pengumpulan Data, Reduksi Data, Penyajian Data (display data), Penarikan Kesimpulan (verifikasi). Agar data valid dan dapat dipercaya, maka dalam penelitian ini akan dilakukan "Triangulasi data".

C. Hasil Penelitian dan Pembahasan

Memberikan Kemudahan Bagi Guru dalam Mengimplementasikan Proses Pembelajaran

1) Pendapat Guru

Dari wawancara yang dilakukan dengan guru yang membuat modul dan yang memakai modul, diketahui bahwa 
modul memberikan banyak kemudahan. Diantaranya wawancara yang dilakukan dengan guru IM yang mengatakan bahwa modul melatih kemandirian siswa untuk belajar sendiri, berikut hasil wawancara guru IM.

“Modulmemilikibanyak keunggulan, keunggulan itu salah satunya yang dapat dirasakan adalah siswa dapat belajar sendiri dirumah, serta memudahkan siswa dalam menerapkan materi sesuai dengan indikator karena pencapaian sudah dipahami oleh guru yang membuat modul untuk lingkungan sendiri". (wawancara tanggal 6 mei 2015)

Lebih dari itu kata guru bukan hanya dapat belajar sendiri tatapi guru yang bukan mata pelajaran sejarah dapat pula menggunakan modul sejarah, berikut wawancara dengan guru diantaranya yang dikemukakan oleh guru SP.

“Modul memiliki kemudahan baik untuk siswa dan guru, bagi siswa lebih mudah memahami materi, siswa bisa belajar sendiri dirumah, bagi guru yang bukan sejarah dapat memahami materi saat menggantikan guru sejarah yang berhalangan hadir pada jadwalnya". (wawancara tanggal 8 Mei 2015)

Berdasarkan pendapat dari kedua guru diatas maka modul sangat positif, dan ini juga telah diakui oleh kepala sekolah, berikut wawancara dengan pemimpin sekolah Pak RDS mengatakan:

“Jika pembelajaran terkait dengan hal yang sifatnya hafalan,disaat guru menerangkan hal-hal yang prinsip dan hal-hal detil sudah ada pada modul. Untuk pembelajaran itu akan mempermudah siswa mengulang pelajaran yang sudah ada di rumah". (wawancara 7 Mei 2015)

2) Pendapat Siswa
Selain dari wawancara dengan para guru di atas, juga ada wawancara dengan beberapa siswa yang yang diajar oleh para guru tersebut. Berikut yang disampaikan oleh siswa DN, RJ, IP dan DO siswa kelas $\mathrm{X} 1$ terkait keunggulan modul bahwa:

"Ya. Modul memberikan kemudahan dalam proses pembelajaran, salah satunya kami dapat belajar sendiri di rumah, apabila pelajaran yang disekolah belum selesai" (wawancara tanggal 9 Mei 2015)

Bukannya hanya dapat belajar sendiri, siswa juga tidak perlu mencatat ulang materi kedalam buku catatan. Berikut wawancara dengan siswa kelas X2, yaitu siswa IRI, DS, dan SA yang mengatakan bahwa:

"Secara keseluruhan menurut kami modul itu lengkap, mudah dipahami, dan lebih rinci, banyak dilengkapi dengan gambar, sehingga lebih paham. Kita tidak perlu mencatat ulang pelajaran dalam buku catatan". (wawancara tanggal $10 \mathrm{Mei}$ 2015).

Bukan hanya materi yang lengkap dan siswa tidak perlu mencatat ulang materi dalam buku catatan, modul juga disajikan dengan gambar-gambar dan latihan dalam modul banyak, berikut wawancara dengan siswa TN, ZAHA, DO, FH dan IP kelas X1 mengatakan bahwa:

“Gambarnya lebih banyak dibandingkan dengan LKS. Isi modul lebih kepada materi tidak berteletele, latihannya lebih bermutu. Mudah dipahami dari LKS". (wawancara 9 Mei 2015)

Berbeda dengan guru dan siswa yang mengatakan modul memiliki keunggulan dan kemudahan. Ada juga siswa yang mengatakan materi dalam modul kurang lengkap dan jawaban soal-soal susah 
ditemui dalam modul. Berikut wawancara dengan siswa HPS, RR, dan RF siswa kelas X1 tekait kelemahan modul, mengatakan bahwa:

"Materi dalam modul kurang lengkap karena soal-soal yang ada dalam modul jawabanya sering tidak ditemukan didalam modul" (wawancara tanggal 9 Mei 2015).

Hasil wawancara diatas juga dibenarkan oleh VSA, ADA, NT kelas X1 mengatakan bahwa materi dalam modul kurang ada penjelasannya, saat diskusi kelompok ada materi kelompok yang tidak ditemukan dalam modul.

"Modul yang disajikan kurang lengkap karena penjelasannya hanya sedikit sehingga membuat saya bingung, materi yang tidak ada dalam modul kami cari di internet" (wawancara tanggal $9 \mathrm{Mei}$ 2015).

Kemudian siswa TN kelas X1 mengatakan bahwa modul kurang lengkap karena saat diskusi kelompok, pembahasan dalam kelompok saya tidak terdapat dalam modul, jadi untuk mencari bahan diskusi saya, saya cari di internet". (wawancara 11 Mei 2015)

Disisi lain siswa juga mengatakan bahwa modul sama dengan LKS dan materi dalam odul juga kuarang lengkap, berikut wawancara dengan siswa $\mathrm{HF}$, PS, FPD, LT dan NT siswa kelas X1 mengatakan bahwa:

"Modul kurang lengkap karena kurang mencakup semua bahan pelajaran didalamnya, kalau mengenai kemudahan saya belum bisa menemukanya karena materi yang saya cari masih belum bisa saya temukan dimodul. Modul sama saja dengan bahan ajar lain seperti LKS masih kurang lengkap". (wawancara 9 Mei 2015)
Memberikan Konsisten Implementasi Pembelajaran. Konsisten adalah adalah derajat dimana inovasi tersebut dianggap konsisten dengan nilai-nilai yang berlaku pengalaman masa lalu dan kebutuhan pengadopsi. Artinya inovasi akan diadopsi jika sesuai dengan kebutuhan, kepercayaan dan nilai-nilai pengadopsi tersebut. Sesuai dengan Undang-undang Nomor 20 tahun 2003 pasal satu ayat 2 yang berbunyi sebagai berikut

"Pendidikan nasional adalah pendidikan yang berdasarkan Pancasila dan Undang-undang Dasar 1945 yang berakar pada nilai-nilai agama, kebudayaan nasional Indonesia, dan tanggap terhadap tuntutan perubahan zaman".

Maksud dari ayat diatas undangundang ini mengharuskan pendidikan berakar pada kebudayaan nasional dan nilai-nilai agama berdasarkan Pancasila dan Undang-Undang Dasar 1945. Ini berarti teori-teori pendidikan dan praktikpraktik pendidikan yang diterapkan di Indonesia harus berakar pada kebudayaan Indonesia dan agama (Pidarta, 2009: 45)

1) Pendapat Guru

Dalam sebuah modul harus ada ada acuan yang dipakai dalam pembuatan modul, artinya sebuah modul harus konsisten berdasarkan nilai-nilai yang berlaku, serta konsisten dalam pelaksanaanya. Berikut wawancara dengan pemimpin sekolah Pak RDS mengatakan bahwa:

"Modul itu konsisten dengan kebijakan dalam dunia pandidikan, karena dalam peroses pembuatan modul terikat pada alat ukur yang ada pada kurikulum yang dipakai disekolah, kurikulum yang dipakai adalah kurikulum 2006 dibuat berdasarkan alat ukur SKL dan KD". 
(wawancara tanggal 7 Mei 2006)

Dalam proses pembuatannya modul dibuat berdasarkan kurikulum, SK, KD dan indikator, agar tujuan dari modul tercapai. Berikut wawancara dengan guru SP yang membuat modul.

"Modul itu konsisten, karena modul dibuat berdasarkan silabus, silabus diambil dari kurikulum 2006. Dari silabus ada SK dari SK ada KD, dari KD ada indikator, indikator tersebut sesuai dengan tujuan pendidikan (wawancara tanggal 8 Mei 2015)

Pendapat dari pemimpin sekolah Pak RDS dan guru yang membuat modul guru SP, juga dibenarkan oleh guru IM yang memakai modul tersebut yang mengatakan bahwa:

"Modul adalah adalah suatu alat bantu untuk menerapkan materi-materi yang dipelajari oleh siswa sesuai dengan kurikulum yang dipakai disekolah dan indikator, jika ada yang tidak sesuai dengan indikator maka guru wajib meluruskan hal tersebut". (wawancara tanggal 6 Mei 2015)

Selain konsisten dengan kurikulum, SK, KD, dan Indikator didalam modul juga terdapat nilai-nila yang yang berlaku saat ini, pernyataan ini disampaikan oleh guru IM bahwa

"Nilai-nilai itu seperti nilai-nilai kebudayan, misalnya materi yang terdapat dalam modul adalah perdaban-peradaban diluar Indonesia, pada peradaban ini terkandung nilai kebudayaan, kepercayaan, mata pencarian, dengan modul bisa membawa siswa kekehidupan zaman dahulu tanpa harus pergi ke Negara lain." (wawancara 6 Mei 2015).

Selain nilai-nilai kebudayaan yang terdapat pada masa lalu. Terdapat juga nilai-nilai kepercayaan dan kebersamaan, berikut wawancara dengan guru SP bahwa:

"Didalammoduladaterkandungnilainilai kebersamaan seperti dalam diskusi, jika anak disuruh untuk mengerjakan soalsoal dan evalusi harus berkelompok maka harus dikerjakan secara bersama-sama dengan kelompoknya, jagan dibiarkan belajar sendiri, karena Tuhan maha melihat dan mengetahui perbuatan kita." (wawancara 8 Mei 2015).

\section{2) Pendapat Siswa}

Apa yang disampaikan oleh guru dan kepala sekolah juga dibenarkan oleh siswa yang memakai modul, bahwa modul konsisten penilaian dan materi, berikut wawancara dengan siswa FH, VSA, LT kelas X1 mengatakan bahwa:

"Modul itu mengasikkan, dengan modul nilai saya menjadi lebih baik, karena jika siswa memberikan kritika, saran dan pendapat dalam modul, maka menjadi nilai tambah untuk siswa tersebut." (wawancara 11 Mei 2015)

Selain konsisten dengan penilaian dan materi, modul juga sesuai dengan tujuan pembelajaran, berikut wawancara dengan siswa TN, IRI, dan SA siswa kelas $\mathrm{X} 2$

"Modul sangat membantu dan juga sesuai dengan tujuan pembelajaran yang disamapaiakan guru dalam proses belajar mengajar". (wawancara 12 Mei 2015)

Selain konsisten dengan tujuan, penilaian dan materi, modul juga sesuai dengan nilai-nilai yang berlaku dan dapat diaplikasikan dalam kehidupan seharihari, perdapat ini dikemukakan oleh siswa IRI siswa kelas X2 modul yang dipakai sesuai dengan tujuan pembelajaran yang didalamnya ada nilai-nilai yang dapat 
diaplikasikan dalam kehidupan seharihari, misalnya nilai kebersamaan saat kerja kelompok, kita harus benar-benar bekerja dalam tim dengan kelompok kita, jangan biarkan teman bekerja sendiri didalam kelompok, karena ini adalah masalah bersama yang harus dipecahkan bersama (wawancara tanggal 10 Mei 2015)

Pada sisi lain terdapat siswa yang tidak setuju dengan konsisten modul dalam pelaksanaannya, siswa tersebut mengatakan bahwa tujuan modul ada yang sesuia ada yang tidak, berikut wawancara dengan siswa MFAS, MRBP, RF siswa kelas X1 yang mengatakan bahwa:

"Modul ada yang sesuia dengan tujuan dan ada yang tidak sesuai, kadangkadang sesuai kadang-kadang tidak, bisa dikatakan ada bolong-bolongnya". (wawancara 12 mei 2015)

Pernyataan di atas juga dibenarkan oleh teman sekelas MFAS, MRBP, dab RF yaitu Hal siswa ADD dan HPS kelas X1 yang mengatakan:

"Modul kurang membantu dalam proses belajar mengajar, dalam tujuan pembelajaran juga kurang, dan sepertinya masih kurang karena masih ada yang belum lengkap". (Wawancara 9 Mei 2015)

\section{Kerumitan Dalam Pemakaian Modul}

Pendapat Guru

Kerumitan dalam penggunaan modul hampir tidak ada, karena semua siswa memakai modul, jadi bahan pegangan guru dan siswa semuanya sama. Kalaupun ada yang rumit itu terletak pada penggunaan media pembelajran. Berikut adalah wawancara dengan guru yang membuat modul yaitu buk SP mentakan bahwa:

"Sampai saat ini sudah hampir 5 tahun saya membuat modul insyallah belum mengalami hambatan, karena sumber-sumber yang digunakan bayak yang diambil dari buku-buku dan internet. Kalau dalam proses pembelajaran tidak rumit, yang rumit adalah media pendukung karena media pendukung yang sesuai dengan perkembangan situasi dan kondisi saat ini, terkadang informasi yang diperlukan belum bisa diakses lewat internet, sehingga masih menggunakan media yang sudah ada (tidak update) yang akan dimasukkan dalam power poin". (wawancara tanggal 8 Mei 2015)

Pendapat diatas dibenarkan oleh guru IM yang memakai modul yang dibuat oleh guru SP, berikut wawancara yang dilakukan pada tanggal 6 Mei 2015 denga guru IM

“Penggunaan modul tidak mengalami kesulitan yang sulit adalah pemungutan dananya, proses belajar mengajar tidak mengalami kesulitan karena modul dibawa pulang, jika tidak mengerti maka siswa akan bertanya pada guru atau akan dibentuk tugas diskusi yang akan dipecahkan bersama-sama".

\section{1) Pendapat Siswa}

Selain itu, penelitijuga mewawancarai siswa yang belajar sejarah dengan guru IM dan SP, yang mengatakan bahwa dalam pemakain modul siswa tidak mengalami kesulitan. Berikut wawancara peneliti dengan siswa IP, DS dan SA kelas X2 mengatakan bahwa:

"Selama memakai modul kami tidak mengalami kesulitan, dan modul secara keseluruhan sudah lengkap dan mudah dipahami karena materi pada materi manusia purba saya lebih paham. Saya lebih bisa mengerti akan perkembangan manusia diawal masa purba" (wawancara 9 Mei 2015). 
Berbeda dengan siswa diatas, ada sebagian siswa yang merasa mengalami kesulitan dalam penggunaan modul, terutama dalam mencari jawaban soalsoal didalam modul. Berikut wawancara dengan siswa kelas $\mathrm{X} 1$ yaitu ZAHA, DG, MRBT, dan RR yang mengemukakan pendapat yang berbeda dengan siswa kelas X2 yaitu:

"Ada kerumitan, kerumitannya terletak pada soalnya yang susah dicari jawabannya dalam modul, terkadang kami mencari jawaban lewat internet. Kalau paket sudah habis maka saya tidak bisa menggunakan internet untuk menjawab soal-soal, terkadang lebih jelas LKS karena isinya yang hanya poin-poinnya saja" (wawancara tanggal 12 Mei 2015)

a. Dapat diauji dan keterpakaian sangat tinggi

1) Pendapat Guru

Modul dapat diuji jika keterpakaian modul sangat tinggi, artinya dipakai oleh semua adaopter dalam lingkungan tertentu. Berikut wawancara dengan Pemimpin sekolah Pak RDS mengatakan bahwa:

“Modul itu keterpakaiannya sangat tinggi karena materi dibuat berdasarkan KD disusun berdasarkan urutan sesuai dengan analisi yang telah dibuat guru yang bersangkutan. Guru mampu membuat modul dengan baik dan bagus, setidaknya guru telah mendekati sesuia dengan tuntutan dari SKL, KD dan Tujuan". (wawancara tanggal 6 Mei 2015)

Wawancara dibuktikan melalui observasi yang dilakukan peneliti pada tanggal 19 Mei 2015 di kelas X4 terlihat dalam proses pembelajaran seluruh siswa memakai modul, kalau ada bahan ajar lain itu hanya sebagai pelengkap saja.
Semua bahan yang disampaikan guru ada pada modul sehingga siswa tidak perlu mencatat, semua yang dianggap penting digaris bawahi oleh siswa, jika menemukan tambahan materi dalam proses belajar mengajar siswa bisa menulis materi tersebut dalam modul karena bagian belakang modul sudah disediakan halaman untuk mencatat materi tersebut.

2) Pendapat Siswa

Pendapat kepala sekolah juga dibenarkan oleh semua siswa memakai modul. Hal ini disampaikan oleh siswa DG dan DS kelas X2 yang mengatakan bahwa:

"Modul itu semua siswa harus memilikinya, keterpakaian modul di SMA 6 sangat tinggi, semua materi sudah ada didalam modul dari semester 1 sampai 2, modul juga hanya dipakai di SMA Negeri 6 saja, sekolah-sekolah lain di padang tidak memakai modul" (wawancara tanggal 11 Mei 2015)

Selain kelas $\mathrm{X} 2$, peneliti juga mewawancari kelas $\mathrm{X} 1$ yakni siswa NT, FPD, ISA, DN, FH, dan ZAHA yang memakai modul terkait dengan keterpakaian modul di SMA Negeri 6 Padang. Semua mengemukakan hal yang sama bahwa:

"Semua siswa wajib memiliki modul, karena disekolah LKS jarang digunakan apalagi modul lebih murah dibanding LKS, dan modul lebih lengkap, lebih tebal dan menerangkan secara detail". (wawancara 9 dan 10 Mei 2015)

b. Dapat Diamati serta Perubahan Yang Dirasakan

\section{1) Pendapat Guru}

Dapat diuji modul tersebut bila modul memberikan kemudahan dalam 
penggunaanya serta sesuia dengan situasi dan kondisi adopter. Berikut wawancara dengan guru SP yang mengangatakan bahwa modul disesuikan dengan perkembangan zaman.

“Dalam pelaksanannya modul disesuai dengan situasi, kondisi dan peristiwa, sebagai contoh materi di kelas XII yaitu pemilu, dari materi ini guru mengambil bahan materi dari tahun 1955 sampai 2014. Karena disetiap pemilu itu berbeda-beda peristiwanya, dengan demikian siswa dapat melihat perbedaan pemilu dari tahun 1955-2014 (wawancara 8 Mei 2015). Terkait dengan penguasaan materi siswa, jawabanya adalah "Iya, sebab materi dibuat secara kekinian (update). (wawancara tanggal 9 mei 2015)

Modul juga memberikan perubahan bagi guru yang membuat, yakni kenaikan pangkat oleh guru. Berikut wawancara dengan guru SP yang membuat modul

"Semua siswa memakai modul dan pemimpin sekolah sangat mendukung, karena ada perubahan dan pembaharuan dalam proses belajar mengajar, keuntungan bagi guru yang membuat adalah kenaikan pangkat 1 modul sama dengan nilai 1 angka kredit, untuk naik pangkat harus mencapai 12 kredit" (wawancara tanggal 8 mei 2015)

Disamping dikembangkan berdasarkan situasi perubahan zaman dan kenaikan pangkat oleh guru yang membuat. Modul juga memberikan kemudahan dan dianggap suatu perubahan, berikut wawancara dengan guru IM bahwa:

"Ya. Modul itu sebuah perubahan tapi modul itu tidak mengalami perubahan, hanya saja menyisipkan halhal yang baru, misalnya materi manusia purba tidak mengalami perubahan, tapi jika menemukan hal yang baru maka disisipkan yang baru itu, karena modul harus sesuai dengan kurikulum tidak boleh melenceng harus sesuai dengan SKL, indikator dan tujuan. Lebih kurang sudah hampir 5 tahun terbit. (wawancara tanggal 6 mei 2015)

Pedapat diatas juga dibenarkan oleh pemimpin sekolah Pak RDS terkait modul cocok dengan perkembangan anak, berikut peryataan yang disampaikan oleh Pak RDS:

"Modul cocok dengan perkembangan anak, karena dikembangkan dengan kebutuhan siswa yang memiliki daya serap yang cepat dan mengeluarkan pertnyaanpertanyan yang kritis, pertanyaanpertanyaan itu terkait dengan situasi dan kondisi saat ini. Sebab sekarang ini adalah mendidik dan mengajar, kalau mendidik tingkah lakunya yang dirubah, sedangkan mengajar hanya memberikan materi saja" (wawancara tanggal 6 Mei 2015)

2) Pendapat Siswa

Wawancara juga dilanjutkan dengan siswa kelas $\mathrm{X}$ terkait dengan penggunaan dalam proses pembelajaran dan perubanhan yang dirasakan. Berikut wawancara dengan siswa ZAHA, FH, DO, FDP, dan MFAS kelas X1

"Modul banyak dipakai dalam proses pembelajaran, semua guru sejarah menggunakan modul dalam belajar dan siswa juga diwajibkan memiliki dan memakai modul, jadi garis penting yang diberikan oleh guru tinggal kami garis bawahi di modul". (wawancara tanggal 11 Mei 2015).

Selanjutnya wawancara dengan siswa kelas $\mathrm{X}$ terkait dengan perubahan yang dirasakan siswa setelah memakai modul. Menurut LT siswa kelas X2 "saya 
tidak perlu mencatat, biasa dikerjakan soal-soalnya langsung dalam modul" (wawancara 9 Mei 2015), IP dan SA kelas X1 mengatakan bahwa "Kami dapat menguasai beberapa materi dan lebih cepat dipahami, materinya lengkap dan lebih banyak penjelasan-penjelasan terkait materi pembelajaran. Dan juga memberikan penjelasan dengan sistim intisari yang tidak membingungkan dan lebih mudah dimengerti". (wawancara tanggal 11 Mei 2015)

Hal yang berbeda disampaikan MAS siswa kelas $\mathrm{X} 1$ terkait perubahan yang dirasakan mengatakan bahwa "Kalau saya suka memakai LKS, karena LKS lebih kepada poin-poinnya saja yang dibuat, jadi saya tidak merasa bosan membacanya, saya kurang merasa ada perubahan pada diri saya ketika membaca modul, terlalu tebal dan saya merasa bosan". (wawancara tanggal 11 Mei 2015)

\section{Pembahasan}

Memberikan kemudahan dalam mengimplementasikan proses pembelajaran. Diantara keunggulan yang dapat dirasakan guru sejarah sangat terbantu dengan adanya modul yang dibuat oleh guru sejarah dalam proses pembelajaran karena modul sudah memiliki langkah-langkah yang harus disampaikan dalam kelas karena sudah disusun berdasarkan RPP (Rencana Pelaksanaan Pembelajaran). Bagi guru yang bukan sejarah, ia dapat menggantikan guru sejarah yang berhalangan hadir ketika jadwalnya. Bagi siswa modul memberikan kemudahan dalam proses pembelajaran, siswa dapat belajar sendiri dirumah apabila materi yang dibahas disekolah belum selesai,.

Memberikan konsisten implementasi pembelajaran. Modul dibuat berdasarkan kebutuhan pengadopsi, kepercayaan, dan nilai-nilai pengadopsi sesuia dengan Undang-Undang no 20 tahun 2003 pasal satu ayat 2 yang mengharuskan pendidikan berakar dari kebudayaan nasional dan nilai-nilai agama yang berdasarkan pancasila dan dan undangundang 1945. Berdasrkan penelitian peneliti menemukan bahwa modul yang dibuat di SMA Negeri 6 sudah sesuia dengan kebijakan yang dipakai dalam dunia pendidikan karena terikat pada alat ukur yang ada pada kurikulum

Kerumitan dalam pemakaian modul Dari penelitian yang sudah dilakukan guru dalam membuat modul dan memakai modul tidak mengalami kesulitan dalam penggunaanya, yang sulit hanya media pendukung karena sulit mencari media pendukung yang sesuai dengan perkembangan situasi dan kondisi sekarang. Kerumitan yang dirasakan siswa terletak pada soal-soal yang jawabannya sulit dicari dimodul dan terpaksa siswa mencarinya di internet.

Dapat diuji dan keterpakaian sangat tinggi. Keterpakaian modul sangat tinggi, ini terlihat pada proses pembelajaran karena seluruh siswa memakai modul yang dibuat oleh guru mata pelajaran sejarah.

Dapat Diamati serta perubahan yang dirakan. Proses pembelajaran menjadi mudah karena guru dan siswa memiliki bahan ajar yang sama. Dengan adanya modul sekolah merasa terbantu karena guru yang membuat modul lebih mengetahui kondisi siswa saat belajar sehingga dapat menigkatkan prestasi siswa dibidang akademik. 


\section{PENUTUP}

Modul yang digunakan dalam proses pembelajaran diSMA Negeri6adalah suatu pembaharuan dimana guru membuat sendiri modul dengan memperharikan lima aspek yang dikemukakan oleh Everret M. Rogers yaitu:1) keunggulan dari aspek ini guru dan siswa diberikan kemudahan dalam pemakaian saat proses pembelajaran berlangsung, 2) konsisten adalah kesesuaian modul dengan nilainilai yang berlaku saat ini dan mengacu pada undang-undang No 20 tahun 2003 pasal satu ayat 2 yang berbunyi "Pendidikan nasional adalah pendidikan yang berdasarkan Pancasila dan Undangundang Dasar 1945 yang berakar pada nilai-nilai agama, kebudayaan nasional Indonesia, dan tanggap terhadap tuntutan perubahan zaman", 3) kerumitan pada aspek ini kerumitan tidak begitu dirasakan oleh guru dan siswa saat menggunakan modul, 4) dapat diuji aspek ini dapat dilihat dari keterpakaian modul yang sangat tinggi karena hampir seluruh siswa menggunakan modul, 5) dan dapat diamati adalah perubahan yang dirasakan oleh guru dan siswa setelah modul dipakai. dimana kelima aspek yang dikemukakan oleh M. Rogers sudah dipenuhi oleh modul yang dibuat oleh guru mata pelajaran sejarah. Saran yang harus dipenuhi oleh guru sejarah sebagai berikut.

a. Guru sejarah agar dapat bersamasama dengan

b. Pemimpin Sekolah dan seluruh peserta didik SMA negeri 6 Padang untuk tetap mempertahankan inovasi dalam membuat modul sejarah yang sangat mendukung untuk pembelajaran sejarah, walaupun dalam setiap inovasi tersebut ada yang menerima dan ada pula yang tidak menerima inovasi tersebut. c. Hendaknya mata pelajran lain mengikuti langkah yang diambil oleh guru mata pelajaran sejarah, karena gurulah yang mengetahui perkembangan peserta didinya, dan kebutuhan-kebutuhan peserta didik dalam proses pembelajaran.

\section{DAFTAR PUSTAKA}

B. Suryosubroto. 1983. Sitem Mengajar dengan Modul. Yogyakarta: Bina Aksara.

B. Suryosubroto. 1990. Berapa Aspek Dasardasar Kependidikan. Jakarta: Rineka Cipta

Bambang Warsita. 2008. Teknologi pembelajaran, Landasan dan Aplikasinya. Jakarta: Rineka Cipta

Depdikbud. 2013. Pedoman Pelatihan Implementasi Kurikulum 2013. Jakarta: Depdikbud.

2013. Materi Pelatihan Guru Implementasi Kurikulum 2013. Jakarta: Depdikbud.

Depdiknas. 2008. Panduan Pengembangan Bahan Ajar. Jakarta: Depdiknas

Everett M. Rogers. 1983. Diffusuon Of Innovations. New York: The Free Press

Matthew B. Miles dan A. Michael Huberman. 2009. Analisis Data Kualitatif:: Buku Sumber tentang Metode-metode BaruI (terjemahan Tjetjep Rohendi Rohidi) Jakarta: UI Press

Nana Sudjana. 2001. Penilaian Hasil Belajar Mengajar. Bandung: Trasito

Oemar Hamalik. 2012. Proses Belajar mengajar. Jakarta: Bumi Aksara

Robert H. Lauer. 1993. Perspektif tentang Perubahan Sosial. Jakarta: Rineka Cipta

Suharsimi Arikunto. 2006. Prosedur Penelitian Suatu Pendekatan Praktik. Jakarta:

Rineka Cipta 2010. Manajemen Penelitian. Jakarta: Rineka Cipta 